\section{In Memoriam - Brilliant Chemist, Professor Larisa Tomilova}

Professor Larisa Godvigovna Tomilova passed unexpectedly and suddenly away on January 4, 2021. An outstanding worldwide known phthalocyanine chemist, founder of the leading scientific school she has made a crucial contribution to the synthesis, coordination chemistry, electrochemistry and spectroscopy of this class of tetrapyrrolic compounds, with special attention to the rare earth elements chemistry.

Larisa Tomilova was born in Ukraine (Podvolochisk, Ternopol region) on April 11, 1947. After graduation from the Department of Chemistry of Lomonosov Moscow State University in 1971 she received her Candidate of Chemistry degree (analogous to $\mathrm{PhD}$ ) in 1975 in the same university under supervision of Prof. Valentina Moiseevna Peshkova and Dr. Igor Petrovich Efimov and started her bright carrier at the Organic Intermediates and Dyes Institute (NIOPIK). In 1995 Larisa Tomilova completed her habilitation with the thesis «Substituted mono- and diphthalocyanines of $d$ and $f$-elements: preparation, spectral and electrochemical properties, and prospects for practical Application» and received the Doctor of Chemistry degree. Later she became Professor at Lomonosov Moscow State University, where she taught courses in Organic and medicinal chemistry in the Department of Chemistry. Simultaneously, in 1995 academician N.S. Zefirov invited her to head the laboratory of phthalocyanines and their analogues at the Institute of Physiologically Active Compounds of Russian Academy of Sciences, in which she was the permanent head until 2015, when she decided to hand over leadership to one of her talented students - Dr. Victor Pushkarev.

Starting her scientific carrier with the study of the $\beta$-diketonates of rare earth elements and their mixed complexes during her PhD work, Larisa Tomilova's research interests were always related with coordination chemistry. Her first publication on phthalocyanine chemistry was published in 1977 and was devoted to the synthesis and properties of rhodium(III) tetra-4-tert-butylphthalocyanine. ${ }^{[1]}$ Since then chemistry of phthalocyanines became her main research field and she has published more than 230 papers, 2 books and 12 patents on synthesis, spectral characteriza-

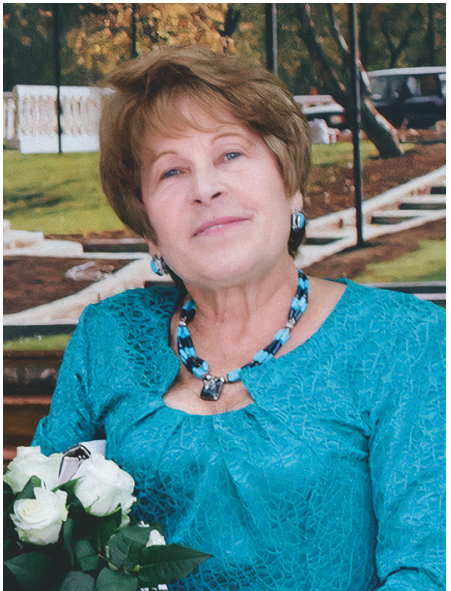

tion, redox and catalytic properties, thin solid films and sensors of phthalocyanines with different metals. But since 1982, the lanthanide chemistry of phthalocyanines became her favorable and lovely research field. ${ }^{[2]}$ After the discovery of sandwich diphthalocyanines by Prof. Kirin and Prof. Moskalev, Larisa Tomilova was among the first to pay attention to the possibility of wide application of these remarkable compounds. She developed approaches to the synthesis of whole series of lanthanides mono- and bisphthalocyaninates, including different substituted derivatives. The spectral peculiarities of different redox forms of diphthalocyanines were established. It was very intrigued story about structure of "green" and "blue" forms of rare-earth elements diphthalocyaninates. ${ }^{[3]}$ Further, the development of single-crystal X-ray diffraction techniques allowed to prove the structure of "blue" form as a triple-decker lanthanide complex. ${ }^{[4,5]}$ Her research group was the first who has synthesized sandwich bisphthalocyanines of $\mathrm{Zr}(\mathrm{IV})$ and $\mathrm{Hf}(\mathrm{IV}),{ }^{[6]} \mathrm{Ti}(\mathrm{IV})^{[7]}$ and demonstrated the absorption of diphthalocyanines in the near-infrared spectral region. ${ }^{[8]}$ In the early $1990^{\text {th }}$ she started to collaborate with the group of Prof. Ricardo Aroca from Windsor University (Canada) in the field of the development of thin films and sensors on the basis of bisphthalocyanines. ${ }^{[9-11]}$ During 1990-1992 years she worked as an invited researcher in the Windsor University. The established collaboration has been expanded by including Valladolid University (Spain), groups of Prof. Jose Antonio de Saja and Prof. Maria Luz RodriquezMendez. ${ }^{[12-15]}$

The main directions of research of Professor Tomilova are summarized in 9 reviews. ${ }^{[4,16-22]}$ Just recently the group of Professor Tomilova has published the chapter in the very interesting review in the «Macroheterocycles» entitled «Macroheterocyclic Compounds - a Key Building Block in New Functional Materials and Molecular Devices»». ${ }^{[23]}$ Last decades, the complexes of phthalocyanine analogues subphthalocyanines, ${ }^{[19,24]}$ naphthalocyanines, ${ }^{[20,25]}$ tetrabenzoporphyrins ${ }^{[21,26]}$ and porphyrazines, ${ }^{[27,28]}$ diazepinoporphyrazines ${ }^{[29,30]}$ were also widely studied. The approaches toward binuclear phthalocyanines of clamshell and ball 


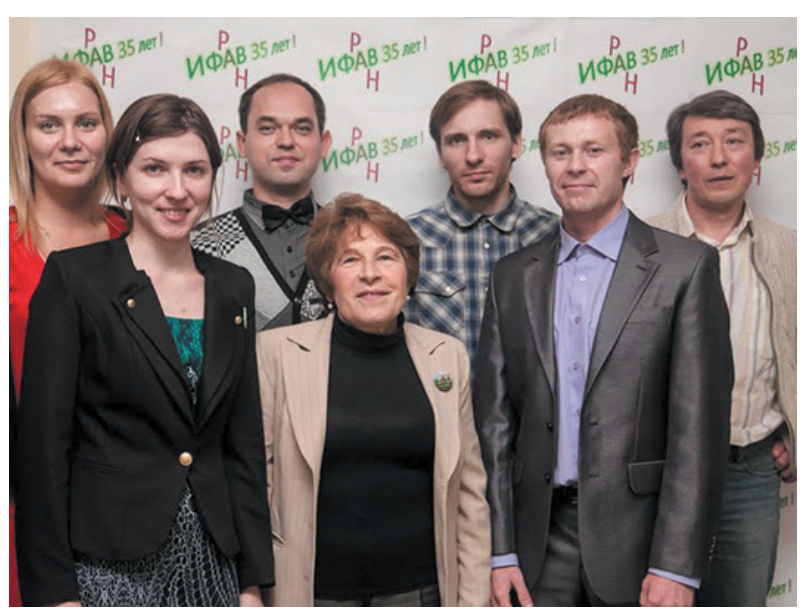

Scientific group of Larisa G. Tomilova

in the Institute of Physiologically Active Compounds of Russian Academy of Sciences, Chernogolovka, Russia, 2013

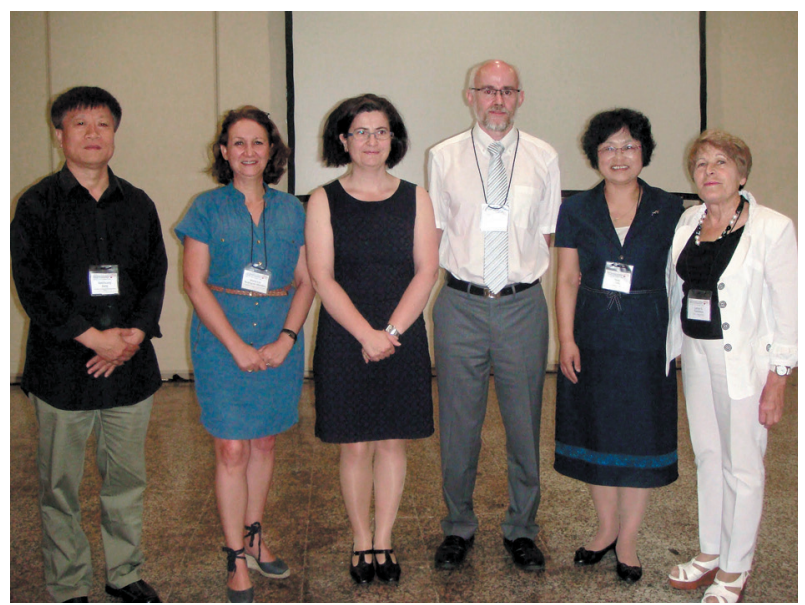

8-th International Conference on Porphyrins and Phthalocyanines (ICPP-8), Istanbul, Turkey. Prof. Larisa G. Tomilova together with invited speakeres of the specialized Symposium «Sandwich tetrapyrrole rare-earth functional molecular materials», July of 2014

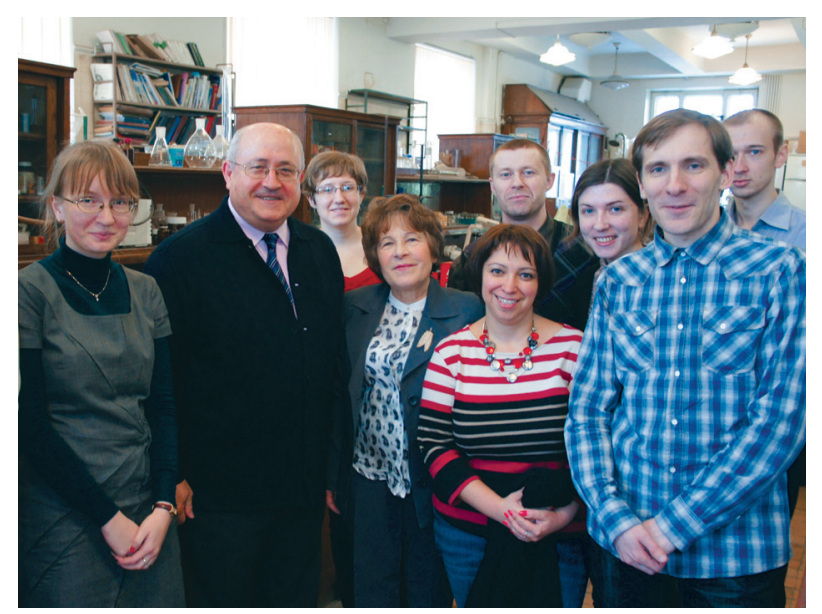

Visit of Prof. Tomas Torres to the laboratory of Prof. Tomilova in the Chemical Department of Lomonosov Moscow State University, 2013

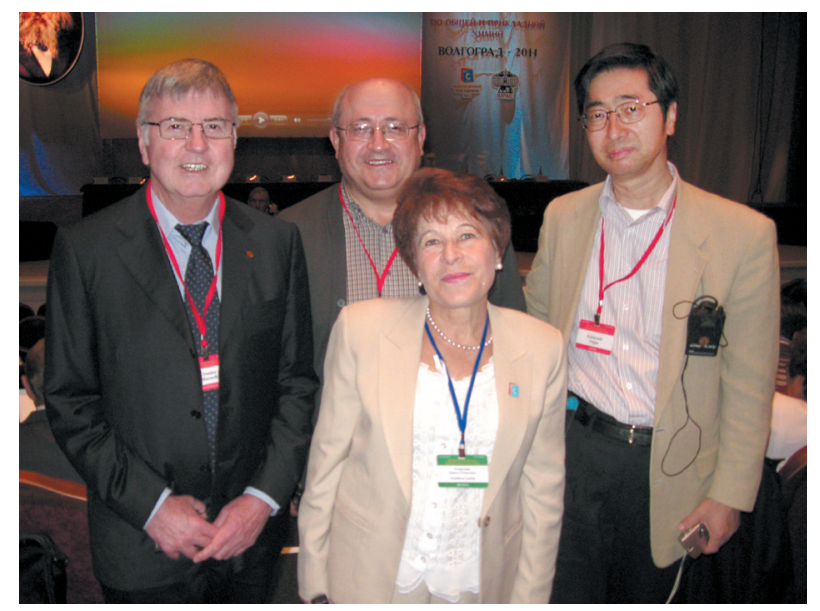

XIX Mendeleev Congress on General and Applied Chemistry, Volgograd, Russia. Prof. Larisa G. Tomilova together with Prof. Tomas Torres and Prof. Nagao Kobayashi and Maxwell Crossley, September of 2011

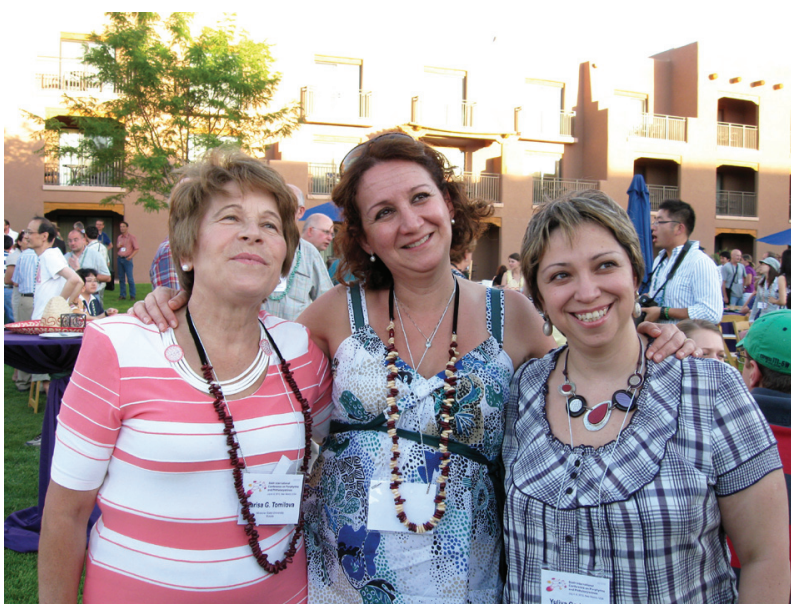

6-th International Conference on Porphyrins and Phthalocyanines (ICPP-6), New Mexico, USA.

Prof. Larisa G. Tomilova together with Prof. Maria Luz Rodriquez-Mendez and Prof. Yulia G. Gorbunova, July 2010 


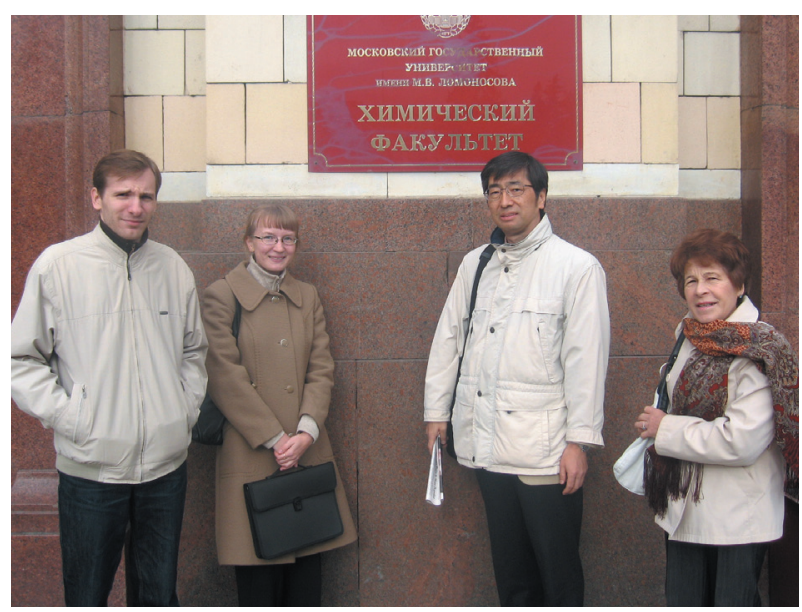

Visit of Prof. Nagao Kobayashi to the laboratory of Prof. Tomilova in the Chemical Department of Lomonosov Moscow State University, 2012

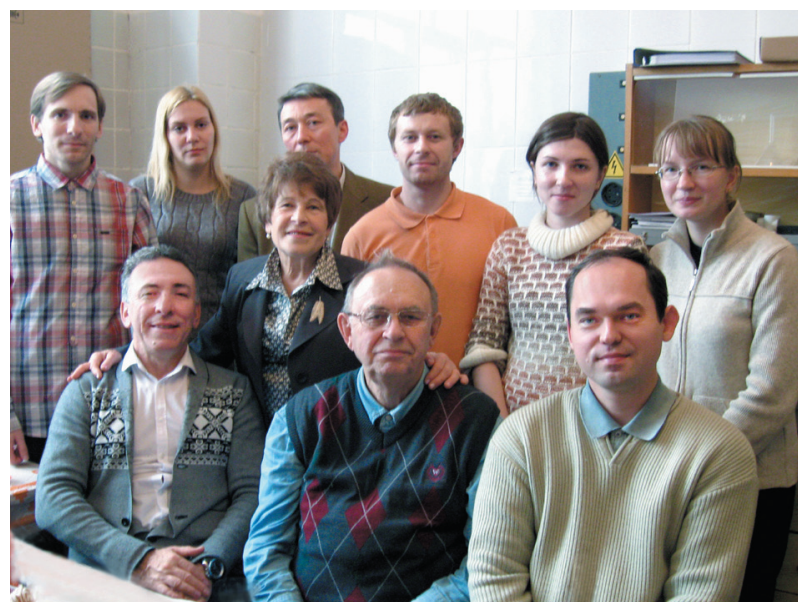

Scientific group of Larisa G. Tomilova in the Institute of Physiologically Active Compounds of Russian Academy of Sciences together with Prof. Geliy V. Ponomarev and Prof. Michael A. Grin, Chernogolovka, Russia, 2013

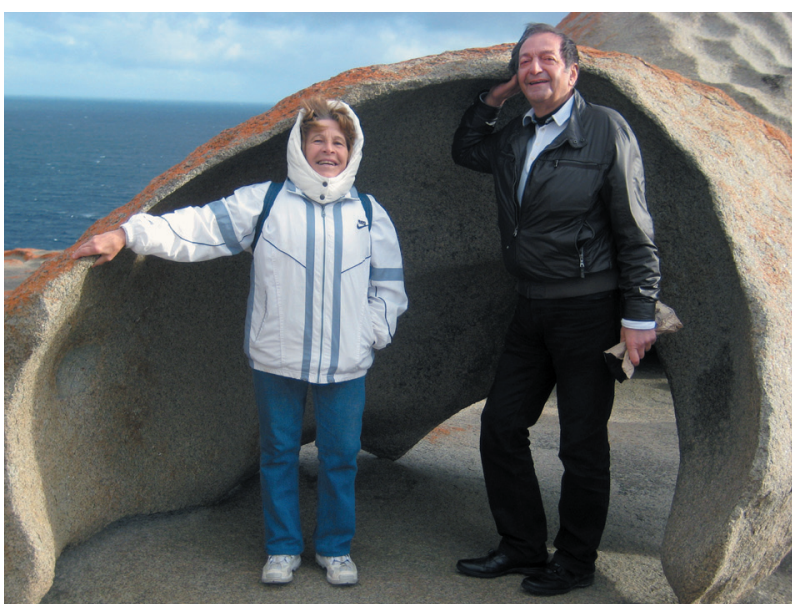

Prof. Larisa G. Tomilova with Academician Aslan Yu. Tsivadze during $39^{\text {th }}$ International Conference on Coordination Chemistry, Adelaide, Australia (Kangaroo island), 2010, July

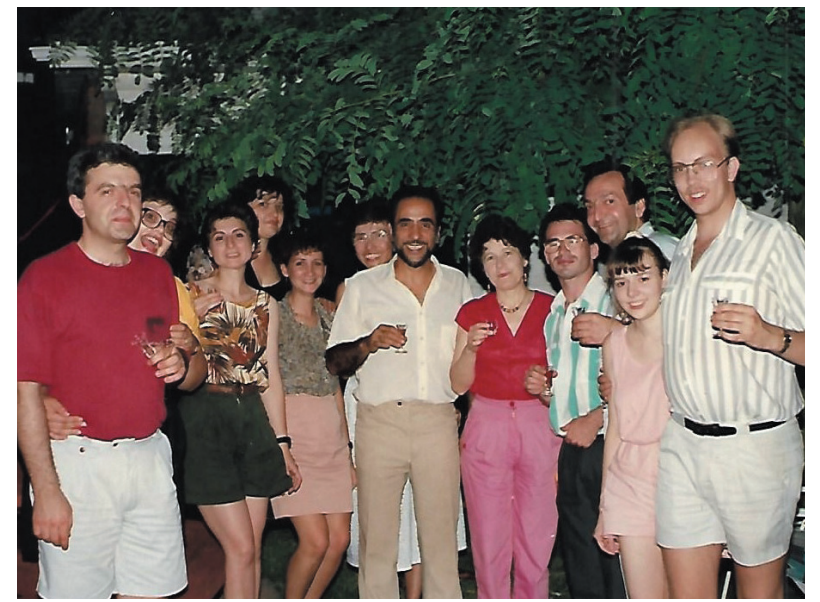

Prof. Larisa G. Tomilova with Prof. Ricardo Aroca scientific group together with Academician Aslan Yu. Tsivadze and Prof. Maria Luz Rodriquez-Mendez in Canada, Windsor, 1991

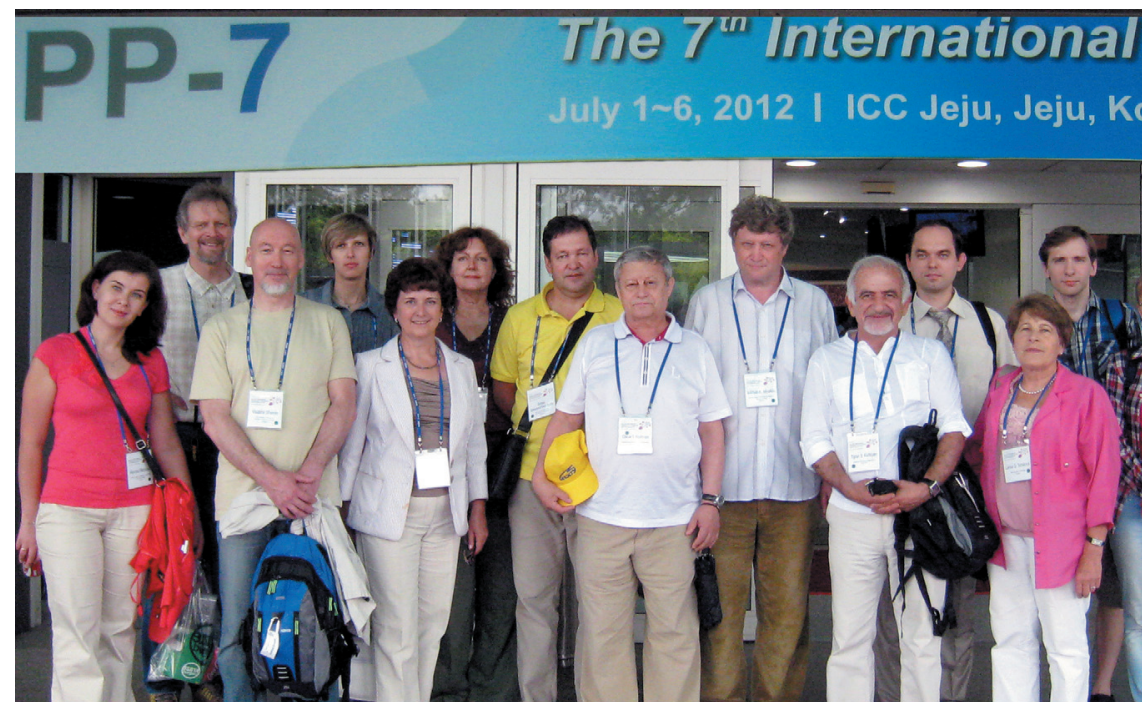

7-th International Conference on Porphyrins and Phthalocyanines (ICPP-7), Jeju, Korea. Prof. Larisa G. Tomilova together with Russian delegation, July of 2012 
types have been also developed. ${ }^{[31-34]}$ The new direction of recent research of Larisa Tomilova group was devoted to phthalocyanine-based catalysis, including synthesis of biologically-active compounds. ${ }^{[35-40]}$ The main achievements of Professor L. Tomilova was summarized in recent book entitled «Advances in the synthesis and investigation of the properties of phthalocyanines and their analogues» published in Russian language in 2019. ${ }^{[41]}$

Under supervision of Professor Larisa Godvigovna Tomilova more than 20 postgraduate students have obtained their Ph.D. degrees and 19 Master degrees. Three of her post-graduate students received the Doctor of Chemistry degree (Yulia Gorbunova, Alexander Tolbin and Victor Pushkarev). Her laboratory in Moscow State University was also very welcome for students: around 40 young researches made their research stage in the group of Professor Tomilova. She has always given special attention and special warmth to teaching of young scientists. By the moment, her students work not only in various Russian places, but also in leading international scientific centers.

Professor Tomilova was a member of the Society of porphyrins and phthalocyanines (SPP) from the beginning of its creation, since 2000. Many of well-known scientists collaborated with her group - Professor Nagao Kobayashi (Japan), Professor Tebello Nyokong and Dr. Jonh Mack (South Africa), Professor Jonathan Sessler (USA), Professor Victor Nemykin (USA), Professor Karolien De Wael (Belgium). Larisa Tomilova participated in all International conferences of porphyrins and phthalocyanines (ICPP), starting from ICPP-1 in Dijon (2000) up to ICPP-10 in Munich (2018). Last decades she always was an invited speaker at the specialized Symposium «Sandwich tetrapyrrole rare-earth functional molecular materials» of ICPP and Mendeleev Congress of General and Applied Chemistry. She was the recipient of several Russian and international grants and awards, among them the Russian Federation Government Award in Science and Technology in 2002 "The development of synthetic approaches towards tetrapyrrole compounds for technical applications”. In 2020 Larisa
Tomilova was elected a corresponding member of Academy of Natural Sciences.

Larisa Godvigovna Tomilova was my teacher. She taught me not only chemistry, but also life. She took care of her students as if they were her own children. In general, this was a person who gave herself to any work wholeheartedly, without the rest. Whether it was research or taking care of her family, weekdays or holidays, Larisa Godvigovna always did everything equally well, with complete immersion in the task. She was very strong and courageous and was not afraid to take up new scientific topics, engage in new collaborations, and start new projects. She was always on the move; it was hard to imagine her stopping! Larisa Godvigovna loved to travel and took her students to international conferences, where she introduced them to new scientific advances and new cities and their cultures with equal interest. She was always surrounded by young people. At the same time, she was an amazing wife, mother, grandmother, and more recently, great-grandmother. Family meant a lot to her. I can't believe she has gone!

Indeed, for the entire scientific community, the news of her death came as a shock. We received condolences from all over the world: from President of Society of Porphyrins and Phthalocyanines, Prof. Karl Kadish (USA), Prof. Nagao Kobayashi (Japan), Prof. Tomas Torres (Spain), Prof. Tebello Nyokong (South Africa), Prof. Maria Luz RodriquezMendez (Spain), Marcel Bouvet (France), Prof. Ayşe Gül Gürek (Turkey), Prof. Vefa Ahsen (Turkey), Dr. John Mack (South Africa), Prof. Alexander Sorokin (France), Prof. Ravindra Pandey (USA), Prof. Claudio Ercolani (Italy), etc. Prof. Kobayashi wrote «Her contribution to phthalocyanine chemistry is large, and it's very sad that I cannot have another opportunity to talk with her about phthalocyanine». These words can be said by many of us who will miss Larisa Godvigovna in Science and Life!

She had a lot of scientific plans that were not destined to come true. The memory of Larisa Tomilova will forever remain in the hearts of all friends, colleagues, and students who knew and respected her.

Yulia G. Gorbunova

N.S. Kurnakov Institute of General and Inorganic Chemistry of Russian Academy of Sciences A.N. Frumkin Institute of Physical Chemistry and Electrochemistry of Russian Academy of Sciences E-mail:yulia@igic.ras.ru 


\section{References}

1. Tomilova L.G., Lukyanets E. Synthesis and structure of rhodium(III) tetra-4-tert-butylphthalocyanine. Zh. Neorg. Khim. 1977, 22(9), 2586-2587.

2. Tomilova L.G., Chernykh E.V., Gavrilov V.I., Shelepin I.V., Derkacheva V.M., Lukyanets E.A. The synthesis, spectral and electrochemical properties of substituted diphthalocyanines of lutecium. Zh. Obshch. Khim. 1982, 52(11), 2606-2611.

3. Tomilova L.G., Chernykh E.V., Lukyanets E.A. Synthesis of blue forms of rare-earth elements. Zh. Obshch. Khim. 1985, 55 (11), 2631-2631.

4. Pushkarev V.E., Tomilova L.G., Nemykin V.N. Historic overview and new developments in synthetic methods for preparation of the rare-earth tetrapyrrolic complexes. Coord. Chem. Rev. 2016, 319, 110-179. https://doi.org/10.1016/j. ccr.2016.04.005.

5. Troyanov S.I., Lapkina L.A., Larchenko V.E., Tsivadze A.Y. Crystal structure of dilutetium(III) tris[tetra(15-crown-5) phtalocyaninate]. Dokl. Akad. Nauk 1999, 367(5), 644-648.

6. Tomilova L., Ovchinnikova N., Lukyanets E. Phthalocyanines and related-compounds .29. Spectral electrochemical study of diphthalocyanines of hafnium and zirconium. Zh. Obshch. Khim. 1987, 57(9), 2100-2104.

7. Tomilova L.G., Dyumaev K.M. The first synthesis of sandwich-type titanium bisphthalocyanines. Mendeleev Commun. 1995, No. 3, 109-110.

8. Tomilova L.G., Chernykh E.V., Ovchinnikova N.A., Bezlepko E.V., Mizin V.M., Lukyanets E. Absorption-spectra of diphthalocyanines in the near-infrared. Optika Spektrosk. 1991, 70(4), 775-778.

9. Battisti D., Tomilova L.G., Aroca R. Spectroscopic characterization of rare earth octa-tert-butylbisphthalocyanine complexes. Chem. Mater. 1992, 4 (6), 1323-1328. https://doi. org/10.1021/cm00024a036.

10. Souto J., Tomilova L.G., Aroca R., de Saja J.A. Spectroscopic studies of Langmuir-Blodgett monolayers of praseodymium bis-phthalocyanines. Langmuir 1992, 8(3), 942-946. https:// doi.org/10.1021/la00039a033.

11. Aroca R., Battisti D., Lukyanetz E.A., Tomilova L.G. Surface enhanced Raman scattering of green and blue lutetium diphthalocyanine. J. Mol. Liq. 1992, 53, 147-153. https://doi. org/10.1016/0167-7322(92)80056-N.

12. Tomilova L.G., Gorbunova Yu.G., Rodriquez-Mendez M., de Saja J.A. Directed synthesis of polyphenyl-substituted lutetium bisphthalocyanines. Mendeleev Commun. 1994, 4, 127-128.

13. Gorbunova Y., Rodriguez-Mendez M.L., Souto J., Tomilova L.G., de Saja J.A. Langmuir-Blodgett films of asymmetrically phenyl-substituted lutetium bisphthalocyanines. Spectroscopy and gas-sensing properties. Chem. Mater. 1995, 7, 1443-1447. https://doi.org/10.1021/cm00056a007.

14. Gorbunova Y., Rodríguez-Méndez M.L., Kalashnikova I.P., Tomilova L.G., de Saja J.A. Langmuir-Blodgett films of bis(octakispropyloxy) samarium bisphthalocyanine. Spectroscopic and gas-sensing properties. Langmuir 2001, 17, 5004-5010. https://doi.org/10.1021/la0102760.

15. Gonzalez-Anton R., Osipova M.M., Garcia-Hernandez C., Dubinina T.V., Tomilova L.G., Garcia-Cabezon C., Rodriguez-Mendez M.L. Subphthalocyanines as electron mediators in biosensors based on phenol oxidases: application to the analysis of red wines. Electrochim. Acta 2017, 255, 239-247. https://doi.org/10.1016/j.electacta.2017.09.168.

16. Tolbin A.Yu., Tomilova L.G., Zefirov N.S. Asymmetrically substituted phthalocyanines: synthesis and structure modification. Uspekhi Khim. 2007, 76(7), 732-744.
17. Tolbin A.Yu., Tomilova L.G., Zefirov N.S. Bi- and polynuclear phthalocyanines: synthesis and study of physicochemical properties. Uspekhi Khim. 2008, 77(5), 460-475.

18. Pushkarev V.E., Tomilova L.G., Tomilov Y.V. Methods of synthesis of lanthanide complexes with tetrapyrrole type ligands. Uspekhi Khim. 2008, 77(10), 938-972.

19. Tolbin A.Y., Tomilova L.G. Subphthalocyanines and their analogues: methods for the synthesis and structure modification. Russ. Chem. Rev. 2011, 80, 531-551. https://doi.org/10.1070/ RC2011v080n06ABEH004198.

20. Dubinina T.V, Tomilova L.G., Zefirov N.S. Synthesis of phthalocyanines with an extended system of $\pi$-electron conjugation. Russ. Chem. Rev. 2013, 82, 865-895. https://doi. org/10.1070/RC2013v082n09ABEH004353

21. Kalashnikov V.V., Pushkarev V.E., Tomilova L.G. Tetrabenzotriazaporphyrins: synthesis, properties and application. Russ. Chem. Rev. 2014, 83, 657-675. https://doi.org/10.1070/ RC2014v083n07ABEH004421.

22. Kuzmina E.A., Dubinina T.V., Tomilova L.G. Recent advances in chemistry of phthalocyanines bearing electron-withdrawing halogen, nitro and $\mathrm{N}$-substituted imide functional groups and prospects for their practical application. New J. Chem. 2019, 43, 9314-9327. https://doi.org/10.1039/C9NJ01755K.

23. Koifman O.I., Ageeva T.A., Beletskaya I.P., Averin A.D., Yakushev A.A., Tomilova L.G., Dubinina T.V., Tsivadze A.Y., Gorbunova Y.G., Martynov A.G., Konarev D.V., Khasanov S.S., Lyubovskaya R.N., Lomova T.N., Korolev V.V., Zenkevich E.I., Blaudeck T., von Borczyskowski C., Zahn D.R.T., Mironov A.F., Bragina N.A., Ezhov A.V., Zhdanova K.A., Stuzhin P.A., Pakhomov G.L., Rusakova N.V., Semenishyn N.N., Smola S.S., Parfenyuk V.I., Vashurin A.S., Makarov S.V., Dereven'kov I.A., Mamardashvili N.Z., Kurtikyan T.S., Martirosyan G.G., Burmistrov V.A., Aleksandriiskii V.V., Novikov I.V., Pritmov D.A., Grin M.A., Suvorov N.V., Tsigankov A.A., Fedorov A.Y., Kuzmina N.S., Nyuchev A.V., Otvagin V.F., Kustov A.V., Belykh D.V., Berezin D.B., Solovieva A.B., Timashev P.S., Milaeva E.R., Gracheva Y.A., Dodokhova M.A., Safronenko A.V., Shpakovsky D.B., Syrbu S.A., Gubarev Y.A., Kiselev A.N., Koifman M.O., Lebedeva N.S., Yurina E.S. Macroheterocyclic compounds - a key building block in new functional materials and molecular devices. Macroheterocycles 2020, 13, 311-467. https://doi.org/10.6060/mhc200814k.

24. Shvedene N.V., Otkidach K.N., Ondar E.E., Osipova M.M., Dubinina T.V., Tomilova L.G., Pletnev I.V. PhenoxySubstituted Boron Subphthalocyanine as a Ionophore of IonSelective Electrodes. J. Anal. Chem. 2017, 72 (1), 95-104. https://doi.org/10.1134/S1061934817010117.

25. Kazak A.V., Marchenkova M.A., Dubinina T.V., Smirnova A.I., Tomilova L.G., Rogachev A.V., Chausov D.N., Stsiapanau A.A.; Usol'tseva N.V. Self-organization of octaphenyl2,3-naphthalocyaninato zinc floating layers. New J. Chem. 2020, 44, 3833-3837. https://doi.org/10.1039/C9NJ06041C.

26. Kalashnikov V.V., Chernyak A.V., Kalashnikova I.P., Pushkarev V.E., Tomilova L.G. 5-Phenyl- and 5,10-diphenyltetrabenzoporphyrins: novel synthetic approach, physicochemical study with an emphasis on NMR spectroscopy, and identification of benzylated Dderivatives. Dyes Pigm. 2020, 175, 108130. https://doi.org/10.1016/j.dyepig.2019.108130.

27. Kosov A.D., Dubinina T.V., Borisova N.E., Ivanov A.V., Drozdov K.A., Trashin S.A., De Wael K., Kotova M.S., Tomilova L.G. Novel phenyl-substituted pyrazinoporphyrazine complexes of rare-earth elements: optimized synthetic protocols and physicochemical properties. New J. Chem. 2019, 43, 3153-3161. https://doi.org/10.1039/C8NJ05939J.

28. Dubinina T.V., Borisova N.E., Sedova M.V., Tomilova L.G., Furuyama T., Kobayashi N. Synthesis and spectral properties 
of nonclassical binuclear thienoporphyrazines. Dyes Pigm. 2015, 117, 1-6. https://doi.org/10.1016/j.dyepig.2015.01.023.

29. Tarakanov P.A., Tarakanova E.N., Dorovatovskii P.V., Zubavichus Y.V., Khrustalev V.N., Trashin S.A., De Wael K., Neganova M.E., Mischenko D.V., Sessler J.L., Stuzhin P.A., Pushkarev V.E., Tomilova L.G. Optical readout of controlled monomer-dimer self-assembly. Dalton Trans. 2018, 47, 14169-14173. https://doi.org/10.1039/C8DT00384J.

30. Tarakanova E.N., Trashin S.A., Simakov A.O., Furuyama T., Dzuban A.V., Inasaridze L.N., Tarakanov P.A., Troshin P.A., Pushkarev V.E., Kobayashi N., Tomilova L.G. Double-decker bis(tetradiazepinoporphyrazinato) rare earth complexes: crucial role of intramolecular hydrogen bonding. Dalton Trans. 2016, 45, 12041-12052. https://doi.org/10.1039/C6DT01779G

31. Tolbin A.Y., Ivanov A.V., Tomilova L.G., Zefirov N.S. Synthesis of 1,2-bis(3,4-dicyanophenoxymethyl) benzene and binuclear zinc phthalocyanines of clamshell and ball yypes. J. Porphyrins Phthalocyanines 2003, 7, 162-166. https://doi.org/10.1142/S1088424603000227.

32. Tolbin A.Y., Pushkarev V.E., Nikitin G.F., Tomilova L.G. Heteroligand and heteronuclear clamshell-type phthalocyanines: selective preparation, spectral properties, and synthetic application. Tetrahedron Lett. 2009, 50, 4848-4850. https:// doi.org/10.1016/j.tetlet.2009.06.048.

33. Pushkarev V.E., Tolbin A.Y., Zhurkin F.E., Borisova N.E., Trashin S.A., Tomilova L.G., Zefirov N.S. Sandwich double-decker lanthanide(III) "intracavity" complexes based on clamshell-type phthalocyanine ligands: synthesis, spectral, electrochemical, and spectroelectrochemical investigations. Chem. - A Eur. J. 2012, 18, 9046-9055. https://doi.org/10.1002/chem.201200361.

34. Korostei Y.S., Pushkarev V.E., Tolbin A.Y., Dzuban A.V., Chernyak A.V., Konev D.V., Medvedeva T.O., Talantsev A.D., Sanina N.A., Tomilova L.G. Sandwich quadruple-decker binuclear lanthanide(III) complexes based on clamshell-type phthalocyanine ligand: synthesis and physicochemical studies. Dyes Pigm. 2019, 170, 107648. https://doi.org/10.1016/j. dyepig.2019.107648.
35. Platonova Y.B., Morozov A.S., Burtsev I.D., Korostei Y.S., Ionidi V.Y., Romanovsky B.V., Tomilova L.G. Oxidation of phenol catalyzed by immobilized phthalocyanine complexes. Mendeleev Commun. 2018, 28(2), 198-199. https://doi. org/10.1016/j.mencom.2018.03.030.

36. Platonova Y.B., Volov A.N., Tomilova L.G. Palladium(II) octaalkoxy- and octaphenoxyphthalocyanines: synthesis and evaluation as catalysts in the Sonogashira reaction. J. Catal. 2019, 373, 222-227. https://doi.org/10.1016/j. jcat.2019.04.003.

37. Platonova Y.B., Volov A.N., Tomilova L.G. Palladium(II) phthalocyanines efficiently promote phosphine-free Sonogashira cross-coupling reaction at room temperature. J. Catal. 2020, 391, 224-228. https://doi.org/10.1016/j.jcat.2020.08.019.

38. Novikov R.A., Levina A.A., Borisov D.D., Volodin A.D., Korlyukov A.A., Tkachev Y.V., Platonova Y.B., Tomilova L.G., Tomilov Y.V. Synthesis of the cationic gallium phthalocyanines and their catalytic application in gallium(III)activated processes for donor-acceptor substrates. Organometallics 2020, 39, 2580-2593. https://doi.org/10.1021/acs. organomet.0c00113.

39. Burtsev I.D., Platonova Y.B., Volov A.N., Tomilova L.G. Synthesis and characterization of tetrakis(allyloxy) substituted $\mathrm{Zn}(\mathrm{II}), \mathrm{Pt}(\mathrm{II})$ and $\mathrm{Pd}(\mathrm{II})$ phthalocyaninates. Macroheterocycles 2020, 13, 126-129. https://doi.org/10.6060/mhc200286t.

40. Platonova Y.B., Volov A.N., Tomilova L.G. The synthesis and antituberculosis activity of 5-alkynyl uracil derivatives. Bioorg. Med. Chem. Lett. 2020, 30, 127351. https://doi. org/10.1016/j.bmcl.2020.127351.

41. Tomilova L.G., Pushkarev V.E., Dubinina T.V., Tolbin A.Yu. Advances in the synthesis and study of the properties of phthalocyanines and their analogues. Moscow State University Publishing House: Moscow, 2019. 240 р. [Томилова Л.Г., Пушкарев В.Е., Дубинина Т.В., Толбин А.Ю. Достижения в синтезе и исследовании свойств фталоичининов u их аналогов; Издательский дом МГУ: Москва, 2019. 240 c.]. 